УДК 373.091.33:81’246.2](410)

DOI: https://doi.org/10.24919/2308-4634.2018.140517

Галина Лотфі Гаруді, здобувач кафедри іноземної мови Національного університету “Львівська політехніка"

\title{
ОСОБЛИВОСТІ БІЛІНГВАЛЬНОЇ ОСВІТИ В АНГЛІЇ ТА УЕЛЬСІ В УМОВАХ ШКІЛЬНОЇ ОСВІТИ
}

У статті охарактеризовано особливості білінгвальної освіти в Англії та Уельсі (послаблення контролю освіти; створення керівних комітетів за конкретними напрямами стандартизації освіти; спрямування на створення умов для навчання; залучення батьків до навчальних індивідуальних програм своїх дітей тощо). Проаналізовано напрям “Стандарти”, що передбачав запровадження Національного навчального плану. Виявлено, щзо білінгвізм Англії значною мірою відрізняється від двомовності Уельсу: в межах Уельсу, погляд на двомовність, носить індиферентнийхарактер, а в Англії переважає недовіра і упередження до білінгвізму та білінгвальної освіти.

Ключові слова: особливості; білінгвальна освіта; Англія; Уельс; шкільна освіта; двомовність.

Jim. 9.

Halyna Lotfi Ghahrodi, Applicant of the Foreign Languages Department National University "Lviv Polytechnic"

\section{CHARACTERISTICS OF BILINGUAL EDUCATION IN PUBLIC SCHOOLS OF ENGLAND AND WALES}

The article describes the peculiarities of bilingual education in England and Wales focusing in general on the modernization and practical application of education in people's lives; the release of education control; the formation of steering committees in specific areas of centralized standardization of education; the orientation towards creating comfortable conditions for learning; parents' involvement in the individual educational programs of their children; the comprehensive complex use of public resources in the official education system. The direction of "Standards" is analyzed here, where we can see the introduction of the National Curriculum, being forecast accordingly as the content of education should become national-oriented and strengthened the centralization of school educational system. The specifics of new forms of knowledge testing (distribution of goals of each subject, lack of a common scientific concept of curricula, unjustified reduction of thematic teaching material due to subject, standardized educational practice, current account of achievements of students, etc. are not sufficiently taken into account) are vividly shown.

It has been revealed that schools, through the introduction of local management policies, received a number of competences in the financial and administrative fields, and became quite independent. It has been found that bilingualism in England is significantly different from the bilingualism of Wales: within Wales, the view of bilingualism is indifferent in nature, and in England, distrust and prejudice prevail over bilingualism and bilingual education (minority languages and their literacy are considered legitimate within their own institutions, homes, churches, mosques, or community places occur within the marginal sector of the economic, or commercial, as well as family business).

It is established that bilingual education in England is considered rather limited, compared with other countries of the world, and Wales in particular, where its function is on a rather higher level.

Keywords: bilingual education; England; Wales; school education, bilingualism.

$\Delta$ ктуальність дослідження. Кінець XX та початок XXI ст. характеризуються процесами трансформування окремих суспільних груп в одне багатомовне суспільство, а точніше сказати багатокультурне суспільство. Володіння двома мовами стало необхідністю багатомовного інформаційного простору. Білінгви - це такі люди, які своєю самобутністю запобігають утворенню будь-яких стереотипів, викорінюють расизм, а також допомагають зберегти мову, культуру і традиції принаймні двох народів для повноцінного функціонування особистості у сучасному суспільстві. Тому білінгву приділяють так багато уваги. Це поняття не лише акумулює нові знання, а й дає змогу почувати себе впевнено і достойно в багатомовному інформаційному просторі сьогодення. У відповідності до національних засад білінгвальної шкільної освіти, кожна держава дбає про забезпечення певних умов, які б сприяли розвитку особистості, творчої реалізації, ефективним вкладом у майбутнє держави та іï кваліфікованих працівників.

Як зазначає Н. Мукан, “основне завдання загальноосвітньої школи полягає у формуванні готовності учнів до розв’ язання складних проблем 


\section{ОСОБЛИВОСТІ БЛЛІНГВАЛЬНОЇ ОСВІТИ В АНГЛІЇ ТА УЕЛЬСІ В УМОВАХ ШКІЛЬНОЇ ОСВІТИ}

економічного, соціального, полікультурного характеру в повсякденному житті. У розвинутих країнах світу розробляються стандарти шкільної освіти, спрямовані на підвищення якості навчального процесу, що передбачає запровадження змін у змісті навчання й учіння, шкільництва загалом" [3, 3]. Система виховної роботи Великобританії має багатовікові традиції, "які базуються на засадах загальнолюдських та національних цінностей, що дають вагомі позитивні результати як у житті цілої країни, так й у становленні окремої особистості. Тому пї вивчення є доцільним і необхідним у процесі модернізації та реформування сучасної освітньовиховної системи України" [5, 121].

Сучасна білінгвальна освіта бореться за забезпечення різноманітності мови націй, інтернаціоналізму, іммігрантів, політичної та економічної інтеграції, рівності людей та збереження миру. Даний феномен багато вивчали впродовж тисячоліть, відтак його продовжують активно досліджувати, виділяючи все нові факти та особливості.

Метою пропонованої статті $\epsilon$ аналіз особливостей білінгвальної освіти в Англії та Уельсі в історико-педагогічномута порівняльному аспектах.

Виклад основного матеріалу. Освіта у розвинених англомовних країнах “охоплює національний і міжнародний сугнісні компоненти. Національний компонент відображає потреби країн у реалізації традиційних ціннісних орієнтацій національного характеру; міжнародний компонент уособлює потреби країн у підготовці фахівців до активного життя у глобалізованому світі. Під впливом транснаціональної вищої освіти на національні системи освіти відбуваються глибинні структурні реформи, зумовлені: конкуренцією, зміною попиту на якість знань і умінь на національному і світовому ринках праці, формуванням нового підходу до організації вищої освіти і підвищення кваліфікації фахівців; скороченням державного фінансування сектору освіти; встановленням соціальної рівності в галузі вищої освіти з метою посилення її ролі як засобу досягнення соціальної мобільності й рівноправності” $[1,17]$. Білінгвальна освіта, як ніщо інше, забезпечує значущу та неупереджену освіту, так само як і освіту, що формує толерантність до інших лінгвістичних та культурних груп. Такі програми “забезпечують загальну освіту за допомогою двох чи більше мов, розвивають багатостороннє розуміння мов та культур і сприяють комплексному розумінню людської різноманітності. Традиційні програми, що навчають другої чи іноземної мови, часто мають на меті використовувати тільки мову, якої навчають, для викладення матеріалу, тоді як програми білінгвальної освіти завжди використовують другу мову в тій чи іншій формі. Залежно від типу навчальної програми з іноземної мови та типу білінгвальної освіти, інколи важко розмежувати білінгвальну освіту та вивчення другої чи іноземної мови. У XXI ст. програми 3 іноземної мови значно інтегрують мову та контент, а отже стають все більш схожі на білінгвальні програми. Зі свого боку білінгвальні освітні програми все більше звертають увагу на експліцитне навчання мови, чим стають схожими на навчальні програми з іноземної мови $[6,215]$.

На сучасному етапі в основу виховного процесу середніх навчальних закладів Великої Британії покладено концепцію пасторальної опіки, коріння котрої сягає давніх часів.

Як зазначає О. Рева, “основними цілями цієї концепції на сучасному етапі $є$ : забезпечення особистісного контактуз кожним учнем та їхніми батьками; контроль за розвитком учнів; надання дітям необхідної підтримки; співпраця з більш широкою освітньою, соціальною та громадською спільнотою, яка спрямована на досягнення основних цілей виховання та ін. На основі аналізу різноманітних наукових джерел встановлено, що оновлення освітньо-виховного процесу Великобританії на початку нового тисячоліття зумовлено принципами демократизму, культуровідповідності, систематичності і спрямоване на максимальне сприяння утвердженню загальнолюдських цінностей, виховання толерантних стосунків між різними народами та культурами, формування європейської громадянськості тощо" [5, 120].

За результатами аналізу Н. Нікольської можна прийти до висновку, що шкільна білінгвальна освіта поширюється в Уельсі не лише завдяки усвідомленню жителів необхідності захищати від занепаду древню мову залишену їм у спадок, але і з освітніх, політичних та культурних міркувань. Люди, які володіють двома мовами, мають більше шансів на працевлаштування. До недавнього часу однією з причин, що гальмували розвиток білінгвальної освіти в Уельсі, була відсутність норм літературної валлійської, яка існувала лише у розмовному варіанті, який до того ж мав кілька діалектів, однак сьогодні ситуація змінилася. В результаті роботи групи лінгвістів було створено сучасний стандарт валлійської мови, який об'єднав норми як літературної, так і розмовної валлійської. Саме в такому вигляді мову використовують у освітньому процесі. Але, 


\section{ОСОБЛИВОСТІ БІЛІНГВАЛЬНОЇ ОСВІТИ В АНГЛІЇ ТА УЕЛЬСІ В УМОВАХ ШКІЛЬНОЇ ОСВІТИ}

як свідчать дані досліджень, поки що у різних районах Уельсу рівень знань населення та їх здатності послуговуватися валлійською мовою значно відрізняються. Виходячи з останніх статистичних даних в 2001 році в Уельсі 20,8\% (приблизно 582 тис. осіб) віком від трьох років володіють валлійською мовою не достатньо, 16,3\% (приблизно 458 тис. жителів) розуміють, розмовляють, читають і пишуть валлійською, 4,9\% (приблизно 138 тис.) тільки розуміють валлійською. Діти віком від 5 до 15 років володіють валлійською мовою найкращим чином, це 40,8 \% жителів Уельсу. Статистичний аналіз показує, що рівень знань валлійської мови учнями початкової школи значно зріс з 13,2 \% в 1987 році до $16,8 \%$ у 2002 році $[4,138]$.

Характеризуючи елементарну освіту на початку XXI ст., слід зазначити, що в її курикулумі відбулися зміни системного характеру, які охоплюють як підходи до його добору, так і засоби трансляції. На сучасному етапі (2013 р.) головними питаннями щодо конструювання курикулуму початкової освіти є питання про місце наукової складової та навчання ІКТ у предметному блоці; інтеграція базових умінь читання, письма та лічби у викладанні всіх предметів; введення сучасної іноземної мови до стандарту початкової освіти; забезпечення інтегрованого підходу до навчання та сприяння особистісному, соціальному й емоційному розвитку учня. Зміни у курикулумі початкової освіти Сполученого Королівства (Англія, Уельс) є відповіддю як на світові, загальноєвропейські суспільно-економічні трансформації, так і на національні особливості розвитку освіти в країні. Ключем до успіху проголошується віднаходження балансу між урахуванням інтересів кожної окремої дитини і потреб суспільств [2, 62].

Якщо узагальнити прояви реформ освіти Англії та Уельсу, то побачимо, що певні кроки зроблено в бік модернізації та практичного застосування освіти в житті людей, з одного боку, та послаблення контролю освіти з іншого, створивши керівні комітети і Агенства, які характеризуються конкретними напрямами щодо централізованої стандартизації освіти. Система зарекомендувала себе, як досить дієва альтернативна складова освіти.

Освітня політика Англії та Уельсу фокусує свою увагуна створення комфортних, сприятливих умов для суспільства, в якому навчається майбутнє країни. Дієвим виявилися залучення батьків до навчальних індивідуальних програм своїх дітей. Громадські ресурси почали комплексно використовуватися в офіційній системі освіти. Планується поступове збільшення вкладу державних ресурсів в освітні програми для одержання успішних результатів. Слід пам'ятати, що будь-які радикальні переміни вимагають фінансування, а це не аби які грошові витрати, які на даному етапі розвитку української освіти було б проблематично здійснити, навіть при бажанні наслідувати приклад розвитку білінгвальної освіти Англії чи Уельсу. Так чи інакше, незважаючи на країну, оновлення системи освітніх програм залишається актуальним і відкритим питанням, а підготовка вчителів повинна здійснюватися непереривним процесом. Вчителям треба займати активну позицію щодо впровадження нових освітніх програм.

3 впровадженням ряду реформ навчальних програм в Англії та Уельсі, система освіти перетворилася “на одну 3 найбільш централізованих та недемократичних узахідному світі” [7]. “Акт Бейкера” повинен був забезпечити “збалансований та широкий зміст освіти”, який би посприяв духовному, культурному, моральному, розумовому і фізичному розвитку учнів у школі та суспільстві загалом, дав змогу підготувати цих учнів до майбутнього дорослого життя, відкритих можливостей, відповідальності та формував би досвід. Такий ряд реформ мав забезпечити потреби і здібності кожного учня зокрема, впроваджуючи настільки суттєво-важливий національний навчальний план [8].

Напрям “Стандарти” передусім передбачав запровадження Національного навчального плану, що відповідно мав забезпечити високий рівень освітніх стандартів. Зміст освіти повинен стати національно-орієнтованим, тобто більш “англійським”. Його ціль - скерувати в бік “відновлення унікальних англійських культурних традицій”, іншими словами - це і мало лягти в основу фундаменту шкільної освіти. Планували більше вивчати релігію, полі культурність проблем міжнародних зав'язків у житті людей. Школа своїм завданням передбачила поворот до класичних методів навчання [9].

Якщо говорити про білінгвізм Англії, то він значною мірою відрізняється від двомовності Уельсу. Доволі часто, хоча і не обов'язково, він проявляється там, де найбільше піклуються про збереження і відновлення мов меншин та корінних народів. В Англії, велике число меншин, які розмовляють рідною мовою вдома, своєму храмі чи обраному за бажанням закладі, висловлюють великий інтерес до білінгвізму. До мов меншин Англії належать: арабська, грецька, хінді, італійська, польська, португальська, іспанська, турецька, українська, мова урду, бенгалі, кантонська, гугераті, мова бенджабі. 
Впродовж останніх двох десятиліть, положення та практика політики і філософії, почали формувати дещо плюралістичні позиції, щодо білінгвальної шкільної освіти. Останнім часом чисельні звіти та дослідження, так як і активні міри та зміни, запроваджені по школах, пропонують продовжувати рух в напрямку розвитку білінгвальної освіти.

Основними способами підвищення освітніх стандартів консервативних реформ освіти стали: запровадження навчального плану; впровадження національної системи перевірки і оцінювання знань школярів; введення, незалежної від держави, інспекції шкіл; формування порівняльних таблиць успішності шкіл.

Загалом, запровадження реформ національної освітньої системи в Англії та Уельсі було актуальним питанням не лише освіти, але й політики, економіки, а також виступало гостро соціальним питанням, яке вимагало негайного вирішення.

Висновки. Особливостями білінгвальної освіти в Англії та Уельсі є модернізація та практичне застосування освіти в житті людей; послаблення контролю освіти; створення керівних комітетів за конкретними напрямами централізованої стандартизації освіти; спрямування на створення комфортних умов для навчання; залучення батьків до навчальних індивідуальних програм своїх дітей тощо. Відповідно стандарти передбачають запровадження Національного навчального плану, згідно якого зміст освіти повинен стати національно-оріснтованим та підсилювалась централізованість освітньої шкільної системи. До особливостей ей нових форм перевірки знань відносять такі як розподіл цілей кожного предмета, відсутність спільної наукової концепції навчальних планів, невиправдане скорочення тематичного навчального матеріалу за рахунок предметного; стандартизована навчальна практика; недостатньо враховане поточне оцінювання досягнень учнів тощо. Білінгвізм Англії значною мірою відрізняється від двомовності Уельсу: в межах Уельсу, погляд на двомовність, носить індиферентний характер, а в Англії переважає недовіра і упередження до білінгвізму та білінгвальної освіти, тому білінгвальна освіта в Англії вважається досить обмеженою, в порівнянні з іншими країнами світу i, зокрема з Уельсом, де вона стоїть на більш високому рівні.

До подальших напрямів дослідження відносимо історико-педагогічний аналіз розвитку білінгвізму в Англії та Уельсі з метою визначення можливостей використання позитивного досвіду в Україні.

\section{ЛІТЕРАТУРА}

1. Авшенюк Н.М. Тенденції розвитку транснаціональної вищої освіти у розвинених англомовних країнах (друга половина XX початок XXI століття): автореф. дис. ... д-ра пед. наук: 13.00.04 / Інститут педагогічної освіти і освіти дорослих НАПН України. Київ, 2016. 39 c.

2. Борисенко I. Етапи розвитку курикулуму початкової освіти в сполученому королівстві Великої Британії та Північної Ірландії (Англія, Уельс) // Педагогічна компаративістика - 2013: трансформації в освіті зарубіжжя та український контекст: матеріали наук.-практ семінару (Київ, 10 червня 2013 р.) / Ін-т педагогіки НАПН України / За заг. ред О.І. Локшиної. - К.: Педагогічна думка, 2013. - с. 61-63.

3. Мукан Н.В. Професійний розвиток учителів загальноосвітніх шкіл у системах неперервної педагогічної освіти Великої Британії, Канади, США: автореф. дис. ... д-ра пед. наук: 13.00.04 / Інститут педагогічної освіти і освіти дорослих НАПН України. Київ, 2011. 40 с.

4. Нікольська Н. В. Функції білінгвальної освіти у суспільстві сполученого королівства Великої Британії та Північної Ірландії// Проблеми сучасної педагогічної освіти. Сер.: Педагогіка і психологія. - 3б. статей: - Ялта: РВВ КГУ, 2014. - Вип. 43. - Ч. 1. - С.137-144.

5. Рева О. Загальна характеристика системи виховної роботи в середніх навчальних закладах Великої Британії // Passus in scienciam: тези доповідей IV студентських читань (Полтава, 19 квіт. 2011 р.) / Полтавський нац. пед. ун-т. ім. В. Г. Короленка; відп. ред. Король Л.Л., Черчата Л. М. - Полтава: ПНПУ, 2011. - С. 120121.

6. Шийка Ю. Аналіз поняттєво-категорійного апарату білінгвальної освіти // Педагогічний дискурс: зб. наук. праць / гол. ред. І. М. Шоробура. - Хмельницький: ХГПА, 2014. - Вип. 17. - С.213217.

7. Chan S.-M. Et al. Primary and secondary education in England and Wales: From 1944 to the present day. 8th Edition. London: UNL. - August 2002. -46 p.

8. Halstead V. The Introduction of the National Curriculum and Assessment in England. Bruxelles: European Yearbook of Comparative Studies in Teacher Education, 1994. - pp. 391407.

9. Pierson Ch. The new governance of education: The Conservatives and Education 1988-1997. Oxford Review of Education. 1998. Vol.24. Issue 1. -pp.131-143. 


\section{REFERENCES}

1. Avsheniuk, N.M. (2016). Tendentsii rozvytku transnatsionalnoi vyshchoi osvity u rozvynenykh anhlomovnykh krainakh (druha polovyna KhKh pochatok KhKhI stolittia) [The Trends of development of transnational higher education in the developed English-speaking countries (second half of the XX beginning of the XXI century)]. Extended abstract of candidate's thesis. Kyiv, 39 p. [in Ukrainian].

2. Borysenko, I. (2013). Etapy rozvytku kurykulumu pochatkovoi osvity $\mathrm{v}$ spoluchenomu korolivstvi Velykoi Brytanii ta Pivnichnoi Irlandii (Anhliia, Uels) [The stages of development of Elementary Education Curriculum in the United Kingdom of Great Britain and Northern Ireland (England, Wales)]. Pedahohichna komparatyvistyka - 2013: transformatsii v osviti zarubizhzhia ta ukrainskyi kontekst: materialy nauk.-prakt seminaru (Kyiv, 10 chervnia 2013 r.). Comparative Pedagogy - 2013: Transformations in Education of Abroad and Ukrainian Context: Proceedings of Scientific and Practical seminar (Kyiv, June 10, 2013). Institute of Pedagogy of National Academy of Sciences of Ukraine. (Ed). O.I.Lokshyna. Kyiv: Pedahohichna dumka. [in Ukrainian].

3. Mukan, N.V. (2011). Profesiinyi rozvytok uchyteliv zahalnoosvitnikh shkil u systemakh neperervnoi pedahohichnoi osvity Velykoi Brytanii, Kanady, SShA [The professional development of teachers of secondary schools in systems of continuing pedagogical education of Great Britain, Canada, USA]. Extended abstract of the candidate's thesis. Institute of Pedagogical Education and Adult Education of National Academy of Sciences of Ukraine. Kyiv, 40 p. [in Ukrainian].

4. Nikolska, N. V. (2014). Funktsii bilinhvalnoi osvity u suspilstvi spoluchenoho korolivstva Velykoi Brytanii ta Pivnichnoi Irlandii [The functions of bilingual education in the society of the United Kingdom of Great Britain and Northern Ireland]. The problems of modern pedagogical education. Series: Pedagogy and Psychology. A Collection of articles: Yalta: RVV KHU, vol. 43, part. 1, pp.137144. [in Ukrainian].

5. Reva, O. (2011). Zahalna kharakterystyka systemy vykhovnoi roboty v serednikh navchalnykh zakladakh Velykoi Brytanii [The general characteristics of the system of educational work in secondary schools in the UK]. Passus in scienciam: tezy dopovidei IV studentskykh chytan (Poltava, 19 kvit. 2011 r.) - Passus in scienciam: Abstracts of the IV Student Readings (Poltava, April 19, 2011). (pp.120-121). Poltava Volodymyr Korolenko National Pedagogical University. (Ed.). Korol L. L., Cherchata L. M. Poltava: PNPU. [in Ukrainian].

6. Shyika, Yu. (2014). Analiz poniattievokatehoriinoho aparatu bilinhvalnoi osvity [An analysis of the concept-categorical apparatus of bilingual education]. Pedagogical discourse: a Collection of sciences. (Ed.). I. M. Shorobura. Khmelnytskyi: KhHPA, vol.17, pp.213-217. [in Ukrainian].

7. Chan, S. M. et al. (2002). Primary and secondary education in England and Wales: From 1944 to the present day. 8th Edition. London: UNL. August 46 p. [in English].

8. Halstead, V. (1994). The Introduction of the National Curriculum and Assessment in England. Bruxelles: European Yearbook ofComparative Studies in Teacher Education, pp. 391-407. [in English].

9. Pierson, Ch. (1998). The new governance of education: The Conservatives and Education 19881997. Oxford Review of Education. Vol.24. Issue 1. pp.131-143. [in English].

Стаття надійшла до редакції 16.05.2018

\title{
G5808न
}

\author{
“Серед безладу знайдіть простоту; серед розбрату знайдіть гармонію; в \\ труднощах знайдіть можливості". \\ Альберт Ейнитейн \\ один з найвизначніших бізиків ХХ століття. \\ Яауреат Нобелівської премії 1921 року.
}

"Жкола- ие майстерня, де формується думқа підростаючого поқоління, треба мічно тримати ї̈ в руқах, яқщо не хочеш випустити з рукмайбутнє”.

\section{Aнрі Барбюс \\ франиузький письменник}

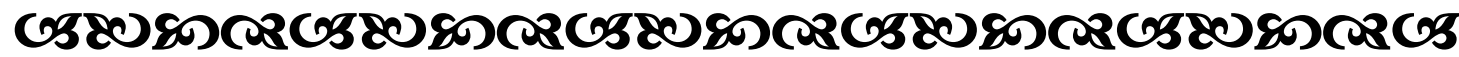

